\title{
Making Their Own Way: Recognizing the Commons in Water Management Wyoming 1900-1925
}

\author{
A. MacKinnon ${ }^{1}$
}

\begin{abstract}
In an era of population growth and climate change, when water management is increasingly important worldwide, it can be useful to reexamine how water management schemes have been crafted, and how they have changed, in the past. In the U.S., where management through private property or central government control are the most familiar approaches to natural resources, it is worth considering an example of a different approach. This paper takes up an instance of Americans who changed an institution of centralized state management into an institution with strong attributes of common property management. Such was the case in the years 1900-1925 in Wyoming with management of water, which is there scarce and sought-after. Historical evidence from court cases, state records and correspondence details how and why, in response to their physical and economic environment, Wyoming water administrators and water users together made institutional change. They moved away from their centralized management system, once lauded as a model for the nation, to create a system far more complex - with aspects recognizable to students of common property.

Key words: Water, institutional change, historical case study, property rights regime, North America
\end{abstract}

\section{INTRODUCTION}

At the heart of many environmental issues today is the need for social institutions that can manage natural resources sustainably, to meet human and ecosystem needs now and in the future. From ocean life to fresh-water supplies to global climate, fundamental natural resources are experiencing or threatened with drastic change. The challenge for society is to match the capacity of its institutions to the nature and scope of the threat, to avoid the most destructive change and help human societies to adapt to the change that does occur.

Scholars such as Berkes, Folke, Holling and Wilson, studying social-ecological systems, have argued for community-based institutions (productively linked or nested with largerscale bodies) plus adaptive management as the pair of social and natural science tools most likely to produce sustainable natural resource management. (Holling, Berkes and Folke 1998; Berkes and Folke 1998; Folke, Berkes and Colding 1998; Wilson 2002) As most major environmental issues today involve common pool resources, the work of scholars such as Bromley, Dietz, E. Ostrom, Blomquist, and Schlager, on the history, design, and outcomes of common pool resource management institutions becomes

\footnotetext{
${ }^{1}$ Adjunct professor, University of Wyoming, School of Environment and Natural Resources; Doctoral Candidate, Natural Resource Economics, Humboldt University, Berlin.
} 
increasingly important. (Bromley 1992; Dietz et al. 2002; Ostrom 1990, 2005, 2007; Blomquist 1992; Schlager and Ostrom 1992) That work points to what kind of community-based institutions could help meet today's environmental challenges.

Resilience in social institutions, echoing the resilience of natural systems, has been shown to be a key factor in the capacity of institutions to serve the cause of sustainable natural resource management. Scholars have argued that resilience is embodied in the cycle, found in ecosystems, of renewal, conservation, creative destruction, and reorganization - giving a system the ability to absorb and adapt to relatively low-level disruption and thereby avoid the rigidity that typically meets up with cataclysmic disruption and irremediable destruction. (Holling, Berkes and Folke 1998)

To begin to address any portion of today's major environmental challenges, then, one must look for evidence of existing resilient institutions, or plan to construct such institutions from scratch. That approach could apply, for instance, to the arid American West, in determining whether there is hope there for sustainable management of fresh water. Since the West is carpeted with intricate networks of water management, the best option would be to find resilience in existing institutions to build upon. Schlager and Blomquist (2008) have argued persuasively that the profusion of water management entities in the West needs to be "embraced" as the flowering of the kind of polycentricity that scholars at the Workshop in Political Theory and Policy Analysis at Indiana University have shown to be productive of effective management policies. Blomquist (1992) has shown how, despite what appears as "chaos" to those enamored of centralized control, in fact a myriad of local groundwater management entities have worked effectively together to reverse dangerous depletion of supplies in complex geophysical and political conditions. Blomquist, Schlager and Heikkila (2004) have demonstrated how the intersection of physical conditions with the varied water management institutions in the region results in differing local capacity to recognize and adopt new scientific understanding in order both to use current water supply and replenish or protect future supply.

Municipal and agricultural entities (such as irrigation districts) and state and federal agencies typically take the starring roles in Western water policy successes or failures. Behind them, however, stand the crucial supporting actors - the systems for allocating rights to water. Those systems are taken into account by all the star players, from the users (who are reliant on them) to the state agencies (who are determined to protect them) to the federal government (who sometimes must rely on them but also must often intervene to deflect the impact that exercise of water rights may have on interests that have no recognized rights.) The systems of allocating property rights in water, peculiar to each state, are institutions that in their own right deserve analysis as to whether they are or can be resilient, whether they offer a foundation on which to build sustainable management institutions.

This paper takes up for examination a very small piece of the water rights systems in the American West - the water rights system of Wyoming, the least populated and most isolated of the Western states. As a first step in attempting to determine whether this system demonstrates resilience, the paper discusses not the current system, but a crucial portion of its early history. To understand and assess an institution - particularly to assess its resilience - one needs to know something of the key points in the path of 
its development and its responses to change over time. One common feature of Western water allocation systems makes it feasible to study their history. These systems typically grant higher priority rights to uses established at the earliest date. As a result they are extraordinarily rich in documentation of their own histories. Wyoming, with state government vaults hoarding almost every scrap of paper that ever affected a water right, is a classic example of why Western states' systems for allocating property rights in water are ripe for detailed analysis of just what those systems are, how they got that way, and what they might offer as potential local bases for a future of sustainable, polycentric management of water in the American West.

Systems for allocating property rights in water in the West have usually been analyzed as straightforward private property systems, much like systems for property in land. In this view, water rights systems in the American West grant private property rights in water, and states regulate those rights, via administrative agencies or courts. Commentators acknowledge that these water rights systems include more "limits" on private property, via regulation, because of the combination of mobility and high subtractability of use that characterizes water resources. (Tarlock 1988) In this view, initially isolated systems of common property management for water that functioned into the mid-19 ${ }^{\text {th }}$ century (by Native Americans, Spanish conquerors, or Mormon colonies) were replaced by private property systems as the scarcity and value of the water resource became apparent in light of a growing population and competing uses. (Tarlock 1988; Anderson 1975). This has been the understanding of Western water systems held and promoted by lawyers, who had not only the greatest need to analyze these systems but also a strong incentive to see them as systems of private property, in order to secure water for farmers and cities despite drought cycles (Tarlock 1988, 70) Seen as private property systems, the Western water laws allocated rights primarily to commodity uses of water. (Wilkinson 1992) In this view, state and federal authorities regulated this private property, under what lawyers term the "police power" of the government to protect its citizens - and again that regulation could be more extensive than with property in land, because of differences between land and water. (Tarlock 1988)

In the last half of the $20^{\text {th }}$ century, societal changes and depletion of water supplies, leading to increased attention to ecological and aesthetic uses of water, threatened to disrupt of these systems. Observers of the systems variously believed that these new pressures could be accommodated by the existing allocation systems, or that the existing systems were moribund and soon to be replaced. (Kenney 2001) The majority arguing for the adaptability of the existing systems recommended reliance on more regulation to accommodate ecological and aesthetic needs, some citing inbuilt flexibility in the regulatory standards and goals embodied in state water law. (Tarlock 1988; Kenney 2001) Throughout this period the weight of expert opinions increasingly favored centralized management. Schlager and Blomquist (2008) have described the mid-20 century penchant to turn to centralized control in the form of "comprehensive management" schemes. Those authors also persuasively argued against this trend in their proposal for "embracing watershed politics." They urged policy-makers and citizens to embrace the many competing centers of authority in water management in the American West - of which the longstanding state water allocation systems are clearly one. 
The Wyoming system of allocating property rights in water is small, relatively recent (initiated only 120 years ago) and, as noted, well-documented. Examination of the history of the Wyoming system leads to an analysis that differs from the widely-held view - the lawyers' view - of Western water as a regulated private property system. Rather than allocating complete property rights to private parties and instituting regulatory controls, the Wyoming system identifies a typical bundle of property rights to water but distributes them between a small state agency and water users (individuals or entities such as municipalities or irrigation districts). Together the agency and its users act as a community: the water rights system covers a large territory but a relatively small number of water users. Which property rights in water are held by the agency and which by users has varied over time, in response to changing circumstances. Now, 120 years after its birth, the system faces new challenges. It is responding in some cases with adaptation, and in some cases with thus-far rigid resistance. Past instances of shifting allocation of property rights in water, however, may suggest capacity for adaptation in the future. At the least, the system's past reveals a locally-based institution that can boast some flexibility.

The Wyoming water rights system might be most usefully characterized as neither a private property system nor quite a common property system, but rather a member of a family of locally-based resource management institutions that includes common property systems. Leading property law scholar Rose terms these institutions "community-based management regimes." She contrasts them with private property systems, which she describes as simply allocating transferable rights to individuals or entities, and then regulating trade in such rights. (Rose 2002.)

Wyoming's system is very far from creating the transferable rights typical of private property; nor does it concentrate rights to water in the state. That is made clear through a key moment in the early development of the Wyoming water rights system, the moment that is the subject of this paper. It is a moment in the system's history that also reveals effective communication and conflict resolution mechanisms among the players in the water rights system (water users and the small state management agency) that researchers typically identify as important criteria for effective local resource management institutions. (Ostrom 1990; Agrawal 2002).

Perhaps these characteristics of Wyoming's system indicate an institution that might ultimately display resilience. The writer is currently undertaking research in the subsequent history of the Wyoming water-rights system to help answer that question. If the Wyoming system has or could achieve capacity for resilience, it might then be able to play a creative role in the polycentric tumult of Western water policy-making that Schlager and Blomquist (2008) posit as the best route to effective, sustainable water management.

Meanwhile, however, the case of Wyoming may suggest that a starting point for understanding the water rights systems of other Western states - especially for the water lawyers - might be to analyze them as "community-based management regimes" rather than as regulated private property systems. 


\section{BACKGROUND TO THE CASE STUDY}

Water in Wyoming offers a particularly compelling study in how people find their own way to managing a common pool resource through a locally-crafted institution. Early on, Wyoming provided textbook tales in other natural resource management options: the "tragedy of the commons" (Hardin 1968) - the creation and then near-destruction of its grasslands cattle industry in just 10 years; and state ownership and control - the adoption of a Progressive-era scientific state water management agency in just 2 years That system was hailed as a model for other Western states (Dunbar 1983).

Subsequently Wyoming transformed that model centralized water management system into something quite different $-\mathrm{a}$ form of community management, the development that is examined here.

Wyoming in the late 19th century was haunted by disasters that had struck the open range industry. This industry, using a common pool resource of grasslands, nearly selfdestructed in the late 1880 s because, while nominally owned by the federal government, the grasslands were actually left as open access. (Larson 1978, 163-94)

In reaction, the men who had overstocked the range took very consciously different steps to manage water, a scarce resource. Wyoming is essentially a high, cold desert a strange new terrain and climate for all these newcomers. Stockmen began to experiment with irrigation - to grow hay as winter fodder for their herds, and to attract new farmer-settlers. (Territorial Engineer 1889, 2, 22-23; State Engineer 1891-2, 10-11)

Who got to use how much water was, however, a matter of great confusion. Unlike a cow, water couldn't carry a brand. Also, its scarcity meant that people often wanted to transport it, to put it where it could be useful. The practice was to nail to a nearby tree (if there was one) a paper stating that you had claimed that water for your ditch, by diverting water from the creek channel and over to some lands that might support hay. (Mead 1903, 69-71, 248-9). ${ }^{2}$ This might not be a very secure claim on which to stake the future.

When grassland productivity crashed after a drought-plus-bad-winter in 1886-87, the larger ranchers, who dominated the territorial legislature, approved public funds to hire someone to get present and future claims to water straightened out. They managed to hire a bright young engineer for the job - a 28-year-old who grew up in moist and verdant southern Indiana but had spent a few years in dry-land Colorado getting an education from water battles there (Kluger 1992; Dunbar 1983).

\footnotetext{
${ }^{2}$ Wyoming did not require that claims be written and filed (in the district court or county clerk's office) until 1886. (Mead 1903, 249; Session Laws of Wyoming 1886, ch. 61; Wyoming Revised Statutes 1887, sec. 1340.) Testimony taken in an 1889 lawsuit over water rights in Crazy Woman Creek in Johnson County Wyoming shows ditches built from 1879 onwards, notice of an 1885 apportionment of water among the ditches being served by notices posted on trees and fence-posts along the ditch routes, and a rush of ditch-owners to register their claims with the district court after passage of the 1886 statute. (Smith v. Devoe, 1889)
} 
In Wyoming, that young man had the pleasure of dealing with an essentially blank slate on which to draw whatever he might see as the perfect water management system for the arid West. He was a young, early Progressive thinker, imbued with the idea that proper management of the valuable water resource in the arid lands of the West could be the foundation of stable communities. The young man, named Elwood Mead, read avidly all he could find about irrigation present and past. Lessons from older civilizations dependent on irrigation, he wrote, showed that proper management of water could lead to "security and content" among the people, while ill-considered systems lead to "disastrous controversies, misery and wrong." (State Engineeer 1895-6, 57). Washington was too far away, and too ignorant of Western conditions, to set up a proper water management system for a place like Wyoming. At the state level, the young engineer believed, there should be scientific expertise to assess and allocate the water resource. That required centralized, state control.

Mead proposed a system of state ownership and control of water resources in an approach that late-20th century advisers might have recommended for a developing country. ${ }^{3}$ The young engineer persuaded the territory's political leaders to proclaim the concept of state ownership of water in the official constitution of the new state of Wyoming that they wrote in $1889 .{ }^{4}$ While other Western state constitutions also mention state or public ownership, Mead pumped life into those words by providing that only the new state government, via a new water agency, could allocate water use rights. No longer could someone claim water by simply taking the water out of the stream and posting or filing a notice. The water governance agency (the "State Engineer's Office") held the crucial right of excluding users from this important resource. A few years later, State Engineer Mead explained (drawing on European examples) that the relation thus created between state and individual water user was essentially that of landlord and tenant - the user rents the water for a set time, and pays a rental fee for it. Though Wyoming people hadn't yet actually accepted the rental fee idea, he believed they would do so, eventually. (State Engineer 1895-96, 59-60) Meanwhile the fundamental provision was that would-be users had to apply to the state for the right to take water. The state's trained engineers would examine the water project plans, large or small, for probable success - considering everything from engineering details to the applicant's finances. They would return applications for modification as necessary. (Territorial Engineer 1889, 96-98; State Engineer 1893-4, 49-58; State Engineer 1895-6, 9; Mead 1903, 266-68). The state engineer could also, however, deny an application for water use - if, as the new constitution put it, the "public interests" so demanded. ${ }^{5}$ Here was the Progressive ideal of expert civil servants helping the settler and the society, saving both from costly mistakes (Hays 1969). Public ownership would be maintained, but

\footnotetext{
${ }^{3}$ Ostrom $(1990,9)$ notes that Hardin (1978) proposed state control to protect natural resources. Mead initially proposed state control of both land and water, with state surveys determining proper location of ditches and irrigated lands and irrigators required to locate according to state surveys. He noted, however, that such a system was impossible without federal lands being ceded to the states - which did not occur. (Territorial Engineer 1889, 12-13, 47-48, 60-61).

${ }^{4}$ The new constitution specifically declared "the water of all natural streams, springs..." (etc) within state boundaries to be "the property of the state." Wyoming Constitution, art. 8, sec. 1.

${ }^{5}$ Wyoming Constitution, art. 8, sec. 3. Permit denial procedures are set in the statutes (Wyoming Statutes Annotated 41-4-503). The first version occurs in Session Laws of Wyoming 1890-91, ch. 8, sec. 34.
} 
economic development would be achieved by putting that water in the hands of private users. The supervision by the expert state engineer staff would ensure a continuing balance between the stability that fostered investment and the flexibility that welcomed innovation. ${ }^{6}$

If an applicant received a permit, he or she received with it a "priority," as against later users. The priority was based on the date of the permit application. Mead thereby accepted the "prior appropriation" concept of "first in time, first in right" that had been the water-use custom in scattered Western communities for nearly 50 years before 1890 (Dunbar 1983). But under Mead's new system, whether a person could acquire that priority right was up to the state engineer's agency. The state alone decided whether to issue a permit - or, in the case of older water uses, whether to confirm a right claimed with that notice on a tree from territorial days. The state and its expert engineers were in control. The state's high court upheld this new system in 1900, 10 years after it was put in effect (Farm Investment 1900) Nationally, the Wyoming system was heralded as the model for Western water administration (Dunbar 1983). The fame of the system propelled its young creator Mead into a career in irrigation and rural development on a national and international level, ending up as head of the U.S. Bureau of Reclamation, where he died in office in the 1930s (Kluger 1992).

During the first ten years in Wyoming of the new system, most of the effort involved in implementation went into establishing the state's authority as gate-keeper, empowered to admit or exclude individuals from water use. Across the state, major stream-wide "adjudications" examined existing users' water claims compared to their actual water use. The state office then issued a "certificate of appropriation" that awarded rights based on actual documented use (and sometimes cutting paper claims by 50 percent) (State Engineer 1895-1896, 150-151; Mead 1903, 257-9). New state permits, too, were to be followed by adjudication and a certificate awarding rights, after an examination showing how the water had actually been put to use (Session Laws 1890-91, 8:36)

The next phase in putting the new system to work began with the new century. Once adjudications were underway and new permits were being issued, around 1900 a new set of questions emerged. What did a user get when he or she got a water right? Could he sell it off to someone else to use somewhere else? Could she hold off for years before really putting all the water involved to use? In sum, what did the state's

\footnotetext{
${ }^{6}$ Mead discussed this balancing act frequently. In 1896, he discussed the fact that his office would sometimes issue a new permit to irrigate lands already covered by an earlier permit - for a project that seemed not to be progressing. In deciding whether to approve a new permit in such a situation, "the Engineer's action will in all cases be governed largely by whether or not the approval or rejection is for the public interest... In all of these cases it has been the effort of the engineer to take such action as would secure the most effective reclamation of land and the best use of our water supply" - whether that meant relying on an early active project to be finished, or issuing a new permit to someone else if the early project was unlikely to be finished. (State Engineer 1895-96, 62-63.) Mead commented that "(t)he success of water laws depends upon their stability." To him that meant the Wyoming water officers must consistently ensure that water rights were defined by actual use, not claims, and that "we give as careful consideration to the right of the last appropriator as is generally given to the first." (State Engineer 1895-6, 39-40.) The section on "Question \#2" in this paper further examines this aspect of Wyoming state engineer's office policy.
} 
permission for use really require of a user, and what choices could that user make in using the water?

Arriving at the answers to those questions turned out to involve considerable debate, and in the end caused considerable change in the water management system. In the years 1900-1925, Wyoming water administrators and users made decisions that moved the entire water management system away from simple state ownership and control. The result was not, however, private ownership of water, but something approaching a common property system of ownership and control of water. The state constitution was not changed (though statutes were), but the people of Wyoming essentially made a fundamental, what can be rightly called a "constitutional" (Ostrom 2005), change in how water was managed.

Two separate controversies in the years 1900-1925 illuminate the changes that took place, and are the focus of this paper.

CHALLENGES AND CHANGE, 1900-25

Question \#1: Can I sell the water?

In 1904, a major controversy came to a head over whether a user with state-confirmed water rights could sell off the water, for use on other lands.

By 1904, the State Engineer's Office, staffed with just a few energetic and dedicated people, found itself dealing with inadequate funding to deal with a rapidly growing workload as more and more lands were settled. The agency had four "superintendents" who lived in the state's four major hydrologic basins, but they were falling behind in their inspections and adjudications of territorial claims and state permits - and they sometimes paid meeting expenses out of their own pockets (State Engineer 1901-02, 54-8,66-70). Nonetheless, the new agency provided something of a network reaching out to on-ground water users, who had as yet few organizations of their own. The four superintendents based around the state, and their part-time staff, pursued their own livelihoods as ranchers or surveyors as well, and communicated regularly with water users. They in turn hired other ranchers part-time as water "commissioners" to monitor and regulate according to priority rights the use of certain streams where water supply routinely fell below demand. The superintendents and the State Engineer met twice a year as the "Board of Control" to confirm adjudications and rule on proposals from users to change a water use or argue that a neighbor had forfeited a water right (Session Laws 1890-91, 8:25-26, 34; State Engineer 1895-96, 37-45; State Engineer 1903-04, 19-20). This made conflict resolution low-cost for users (who did not have to attend) (Mead 1903, 247). For the five board members, however, even getting together was expensive: it took days to cross the state by horseback, wagon or coach, on rough roads, while train service reached only a few places (State Engineer 1897-98, 72; State Engineer 1903-04, 30-35). Centralized state administration looked elegant on paper, but it was patchy in action. That provided opportunities for users to change how the system worked. 
In 1891, the superintendent of Division I, covering south-east Wyoming (the most heavily populated portion of the new state) took evidence for his first adjudication of water claims - on Little Horse Creek, just outside the capitol and largest town, Cheyenne. The creek hosted water users who had been there from territorial times, and after the evidence was taken all four superintendents and the state engineer (meeting as the Board of Control) issued an adjudication sorting out the water rights (and commenting on the difficulty of the task) (State Engineer 1891-92, 73-74) Under the adjudication, the holder of some of the earliest and best rights on the creek was the Springvale Ditch Company, formed by a small rancher. Neighbors immediately challenged the board order and took Springvale to court; as the court case dragged on, the Springvale rancher eventually found himself in financial trouble, and had to sell the place. In the meantime, he made a deal to sell a "half-interest" in one of his key water rights to one of the neighbors who had taken him to court. The neighbor was a company called Little Horse Creek Irrigating Company, headed by a very wealthy man who liked buying ranches and had briefly been territorial governor in the 1880s. The sales contract said Little Horse Irrigating would get to use Springvale's water right, with its early priority, every other week - when Springvale wouldn't use it (Johnston v. Little Horse Creek civil case file 1891-95).

There were a lot of other users on Little Horse Creek - some 67, in fact, and they jostled with each other to get enough water to support their crops (State Engineer 189596,46 .) One was the Johnston family, perhaps a family of small farmers, whose lands on the creek were in between the lands of the Springvale and the Little Horse Irrigating companies. Their water rights, too, were in between those two companies in priority (Johnston v. Little Horse Creek 1904, 223)

The Springvale-Little Horse Creek Irrigating contract settled the court fight as far as Little Horse Irrigating was concerned, but it left the Johnstons out. The Johnstons expected, by virtue of their priority position, to get water when Springvale didn't use it. In the Johnstons' view, Little Horse Creek Irrigating shouldn't be able to take and use that water when Springvale didn't use it just by paying off Springvale under a sales contract (Johnston v. Little Horse Creek civil case file 1891-95).

The State Engineer's Office agreed emphatically with the Johnston family. The water commissioner at work on Little Horse Creek refused to honor the Springvale-Little Horse contract (State Engineer 1895-96. 45-46, 52-53) The Johnstons meanwhile asked the courts - still reviewing the board's adjudication of the creek - to defeat the water sale contract.

The state's top court, however, in 1904 supported the sales contract. The court stated flatly that water users who had water rights could sell those rights to others, to use the water on other lands. (Johnston v. Little Horse Creek 1904, 233-35) The legislature responded promptly, putting the court's ruling into a statute allowing water transfers (Session Laws 1905, ch. 97).

That decision was a bombshell for the State Engineer's Office. Superintendents of the water basins protested in public reports and in 1905 the State Engineer succeeded in 
convincing the state legislature to appoint a special commission on water law (with himself as a member) (State Engineer 1905-06, 81-99).

That special commission on water law took the unusual move of sending out written surveys to water users statewide. The commission found that users opposed water sales. (State Engineer 1905-06, 84) The commission convinced the legislature to enact a new law, which took the users' view and overturned the court decision. The new law forbade the sale of water rights to use on other lands, on pain of loss of priority (Wyoming Compiled Statutes 1910, 724.)

The rule thus clearly stated, and accepted for some decades afterwards, clearly limited the choices available to users. It specifically provided that the actual characteristics of water use - on what lands, in what season, taken from what point on a stream and through what ditches - defined a water right. Accordingly, land and water rights could be sold together, but water rights could not be sold away from their setting, the land. The state engineer who had pushed for the new law saw it as a fundamental step in the definition of a water right, writing a triumphant section entitled "What is a Water Right?" in his 1910 public report after the struggle was over (State Engineer 1909-1910, 17-30)

Here we see a struggle of ten years or more in which men with investment capital and political influence pushed for establishment of a straightforward rule allowing water transfers. They wanted anyone with a water right to be able to sell the water involved, off the land, to anyone else who could find a use for it, wherever that might be. But these men could not get that rule adopted. Instead, the rule adopted imposed even more explicit limits on how users could manage water. What were the factors behind this result?

One was the strong policy concern in the state water agency that water sales away from the original use were inherently pernicious. Mead believed such sales would allow speculation in water. That, in turn, would undercut the establishment of the settled, prosperous communities that he felt could, in an arid territory, only be grounded in orderly water use (State Engineer 1893-94. 34-46). ${ }^{7}$ By the time of the early 1900 s debate over this principle in the Little Horse Creek case in the high court, Mead had moved on to his national and international career, but took vigorous part by mail. His successors, meanwhile, were men he had trained and so imbued with his beliefs that they can fairly be called his disciples. They argued determinedly to outlaw the kind of water sales that Little Horse Irrigating and the state's high court supported.

Other factors may have been equally important, however. ${ }^{8}$ The dispute arose in the most settled part of the state. Irrigators had been using water from Little Horse Creek for

\footnotetext{
${ }^{7}$ Mead suggested that the Little Horse Irrigating Company supported a theory that individual users held an "an absolute property right in water." While that theory might be current in other Western states, Mead declared, it had no validity in Wyoming. (State Engineer 1893-94, 39-40).

${ }^{8}$ The framework that Ostrom proposes for analyzing the "social-ecological systems" (Ostrom 2007) has been helpful here in thinking through the factors that affected the decisions made in Wyoming in this period.
} 
over 20 years before the court decision of 1904 and the subsequent reversal and 1909 defeat of water sales. Meanwhile the creek itself was small, unsuited to investment to enhance the supply (such as major dam construction.) There were also a lot of users, and a water commissioner regularly on hand to monitor their use. These water users, accordingly, had better knowledge of each other and the ecosystem in which they worked than did many other water users in Wyoming at the time. There were also reasonably good ways of sharing information about the issue at hand in the Little Horse Irrigating dispute: the facts would have been well-known on the creek itself and in the nearby capitol city, and also would have been somewhat familiar to other water users in the state. The majority of those users were relatively small ranchers and farmers, carefully reading the biennial public reports of the engineer's office, which were written for that audience. In those reports, successive state engineers assertively followed every development in the Little Horse Creek situation from the 1890s through the first decade of the 1900s. The superintendents around the state, whom many water users knew personally, also cared deeply about the case, as evidenced by their individual comments within the public State Engineer's Reports. ${ }^{9}$ The time that elapsed between the original sales contract in the 1890s to the commission survey of 1906 gave ample time for mulling over the issue involved.

All these factors allowed the State Engineer's Office, the protesting ranch family on Little Horse Creek, and water users statewide to unite around what had become, as they tried to use Wyoming water, a common understanding and concern: Water users working with a limited water resource were interdependent in a way peculiar to people living in arid regions. ${ }^{10}$ So the rule that the state engineer and the water users chose much to the irritation of not only Little Horse Irrigating Co. and its cohorts, but also of

\footnotetext{
${ }^{9}$ The superintendent in northeast Wyoming, for instance, repeatedly stated his opposition to allowing water sales such as that sanctioned by the high court on Little Horse Creek: "It gives the individual a right with public property whereby the State will suffer in the end." (State Engineer 1905-06, 70).

For a sense of the personal relationship between superintendents and water users, it is worth quoting at length from Lou Blakesley, superintendent of Water Division III, the Wind-Big Horn basin in the northwest quarter of the state, who in 1910 commented on his relations with water users: "The people are coming every day for advice and information that they can get in no other place. In this respect, it is one of the most important positions in the State. It deals more directly with the people, knows their needs and conditions better than any other place, and is of the greatest help to them, all of which they fully appreciate. In connection herewith I want to express my appreciation of the help and good will extended to me by the people. They have given me every encouragement in the performance of my duties and without their hearty co-operation the administration of the work of this office would be extremely difficult. They have always been consulted before any great change has been made and their advice has always been good, founded as it is, upon actual experience and observation." (State Engineer 1909-1910, 56).

${ }^{10}$ In 1896 the Superintendent of Division II, in northeast Wyoming, gave a compelling description of interdependence recognized by irrigators on a stream with a limited water supply, in a dry year. "Here is found intense feeling. ( $T$ )heory and pet laws for the government of water are cast aside. The condition is an angry farmer, the half matured crops on his land, which gave promise of an abundant harvest, are rapidly burning up." Irrigators with higher priority rights find they have to accept the Board of Control policy that the water they have rights to cannot be cavalierly moved to new, perhaps more fertile lands they may have lately bought, the superintendent noted. "In times when water was extremely scarce there has been such an intense feeling among his neighbors against such misapplication of water, that in every case he quietly acquiesced in such priority as his new land was entitled to, knowing that this was the only just solution of the problem, and that no other determination would long be tolerated by his neighbors." (State Engineer 1895-96, 150-151.)
} 
later economists advocating free water markets - flatly limited the choices of water users, and ensured they had no significant power of alienation of their right to use water.

The rule that the users and the state engineer chose was, as Mead had insisted, useful to the settled communities that both the water users and the state employees aspired to build. Once uses are established and the nature of the resource means that different uses are likely to be interdependent, users typically need to be able to rely on a regular pattern of use. In Wyoming, that pattern needed protection, and would be disrupted by free alienation of a water right, shifting water resources to other lands and other uses. Mead had noted that the history of traditional irrigation societies proved that recognition of private property in water was damaging (he cited the case of Lombardy) (State Engineer 1895-6, pp. 60-61). Through the 19th and 20th centuries other Western U.S. systems typically have come to adopt some version of a rule avoiding water transfers that "injure" other water rights (Trelease 1984, 209-10). Wyoming's water users and administrators, however, had declared themselves plainly in favor of a view that simply did not include the power of alienation as a right water users could hold.

This decision on the part of Wyoming water users and administrators meant they had drawn distinctions between exactly what rights over water went to irrigators (who could use the water but not sell it away) and what to the state representing the public (which could determine who got a right to use). They had launched, by 1909, upon a detailed delineation of property rights that Barzel points out is peculiarly appropriate for scarce and valuable resources (Barzel 1991, 118-120). They had firmly rejected applying to water the more familiar approach of relatively simple concept of private property ownership, as used by land law. Land law, of course, freely allowed owners of land to alienate that land. The Wyoming Supreme Court had taken that familiar private property ownership approach to water in 1904 when it upheld the Little Horse water sale (Johnston v. Little Horse Creek 1904, 229, 232-3). ${ }^{11}$ The fact that the court's view was repudiated by the users and by the engineer, followed by the legislature, demonstrated a commitment to experiment with new rules, in order to deal with a resource that the users clearly understood to be different from land. ${ }^{12}$

\footnotetext{
${ }^{11}$ The court in upholding the sales contract said to do otherwise would be "to deny the element of property in the water right itself." (Johnston v. Little Horse Creek 1904, 233). That the court would not do.

12 The Wyoming water users and engineer's office, by contrast with the court, had reached the point of understanding that there could be property rights in water that were not like those in land. Mead had described the conceptual challenge at the outset of implementation of his water law system, in 1894: "The difficulty is to draw the line between adequate protection to the appropriator and preservation of the rights of the public. To do this involves to many a new conception of property rights, few being able to conceive of any interest in water short of absolute ownership, which the Board is not disposed to sanction." (State Engineer 1893-4, 124.)

In 1902, Mead expounded on the issue to a general public in a national magazine. "Many who have received rights to a perpetual flow find that the ability to rent or sell the right to other users, during the period of their non-use, is more valuable than their own use of the water. Especially is this true on streams where more land is cultivated than can be watered. The holders of inferior rights live in fear of drought and are willing to pay high prices for the surplus of the earlier appropriations...

"The speculative value of the personal ownership of running water is so great that every argument which the ingenuity and intellect of the best legal talent of the West can produce has been presented to the
} 


\section{Question \# 2: Must I use the water?}

The second key question to come up in the early 1900s was what was required of someone who got a permit for a new use. Was the permit itself enough to confer a right to use water, with a priority position? Could a would-be user be protected against later comers without doing anything else, once a permit was in hand?

The State Engineer's Office believed the answer was clear: "No." There was much more for a would-be user to do. Obtaining a permit was merely the first step towards obtaining a secure water right. To get a secure right to use water, the next requirement was to make a permitted water use become an actual water use.

Under the water laws of 1890 that Mead wrote for Wyoming, state water permits had requirements written into them, clear deadlines for the start and finish of water facility construction, and for getting water actually into use (typically, into irrigation) (Session Laws 1890-91, 8:34). After water had actually reached farm fields, and proof of the water use and permit compliance presented to the Board of Control, the board would issue a certificate of appropriation, recognizing a water right for the amount of water actually used (Session Laws 1890-91, 8:34, 36).

By the early 1900s, the state engineer stated that a permit once issued should be regarded only as a contract with the state. The contract simply allowed a would-be user his chance to put water to use - under certain conditions including deadline compliance. Only compliance with all the contract conditions, including deadlines, would result in someone obtaining an actual right to water (State Engineer 1903-04, 1907-08). ${ }^{13}$

courts in its favor. That it is opposed to public welfare, that it places users at the mercy of appropriators, is not a matter of theory, but of experience. Every objection which has ever been urged against the granting of free and unlimited franchises to the public utilities of cities applies with greater force to giving away the water of Western streams. Nevertheless, city councils continue to grant such franchises, and speculative titles to water continue to be declared vested. The cause is the same in both cases. Organized selfishness is more potent that unorganized consideration for the public interests... Hence it is coming to be that rights to running water .... are being bought and sold and leased like land or live-stock or any other property." (Mead 1902, 12). Mead felt that, by contrast, he had managed to help Wyoming people to adopt organized consideration for public interests. And that would not allow rights to running water to be bought or sold.

${ }^{13}$ In 1904, State Engineer Clarence Johnston wrote: "A permit, can therefore, only be looked upon as a contract the fulfillment of which on the part of the applicant enables him to receive a right to use water on the lands described therein. If the applicant does not sufficiently appreciate the value of the water right sought to comply with terms of the permit, it should be cancelled in order that others who have shown proper diligence may be protected." He included in his report a copy of a letter sent out to all applicants who received a state water permit: "Inclosed (sic) you will find permit, which has been approved and recorded. This is not a water right, but is, in a way, a contract between you and the State. ...Water belongs to the land it irrigates, and not to the ditch or ditch owner. When the works are completed the State Engineer's office should be so notified on the attached stub. Should it be impossible for you to complete the work before the expiration of the time fixed in the permit, you should, if you have good reasons for so doing, apply to the State Engineer for an extension of time. All such requests must be received before the date of expiration, otherwise you will have to refile and lose something in priority by your neglect." (State Engineer 1903-04. 12-13). 
The policy concern was fundamentally the same as in the water-sales question. To allow applicants to proclaim themselves "users" by obtaining a state water use permit, but doing nothing more, was to allow speculators to obtain Wyoming water rights and thereby hamper the growth of self-supporting settlements. Further, the growth of prosperous communities demanded that unsuccessful ideas make way for new, more promising proposals. That again meant that no one should be able to obtain a state permit, fail to use the water, but keep the permit and a claim to the water. If one could do that, she could create for herself the ability to bide her time, and pre-empt others who could put the water to use right away (State Engineer 1895-96, 63-66). ${ }^{14}$ Mead noted early in implementing the state water system that sometimes he would issue a second permit to irrigate lands already covered by an earlier permit - if it appeared that the holders of the first permit simply weren't progressing with their project. Further, Mead had adopted into the state water law the territorial rule (customary in a number of Western states) that a water right could be challenged and lost as "abandoned" if it could be proved that the water involved had not been used for a few years. Water rights had to be in the hands of people who proved successful, in order to put Wyoming water to use quickly, and keep it in use (State Engineer 1895-96, 63-66).

Putting Wyoming water to use if possible, however, turned out to be the more practical goal. In 1902, a puzzling question arose which highlighted the distressing realities of what was really possible. Those realities, in turn, undermined the state engineer's rule on what a state water permit meant.

This question came up in a place that reeked of impossibility - a very different part of the state from the Little Horse Creek area in the southeast, near the capitol city. The place was the Big Horn Basin of northwestern Wyoming, just adjacent to Yellowstone National Park. Yellowstone's wild landscape had been consecrated as the first national park thirty years earlier, and attracted well-heeled visitors and the construction of ambitious hotels; the Big Horn Basin, east of its boundaries, remained frontier country in 1902. Isolated by physical barriers from more settled parts of the state, the region had the harshest terrain, sparsest population (less than 5,000), least economic activity, and least social stability in Wyoming (Davis 1993; Davis 2005). ${ }^{15}$

\footnotetext{
${ }^{14}$ Mead explained the problem to a would-be water project developer, who protested the approval of a new water permit to someone else to water some of the same lands, with water from the same stream, where he already held a permit but had as yet built nothing. Mead informed the protestor: "The fact that you have had a year of unrestricted opportunity with no visible result, as I am informed, and as your letter intimates, makes it much more important that the people desiring to occupy and reclaim these lands should be aided and protected than that development should be retarded in order to protect your prospective profits, and the latter would be the result of a refusal to issue a new permit...It is not to the advantage of the State to promote filings by parties who are not able to build ditches and reclaim lands, and where a reasonable time has been allowed for such construction without any material results new permits will be issued." (State Engineer 1895-96, 64-66, quoting a letter of Feb. 14, 1896, Mead to unstated correspondent.)

${ }^{15}$ In 1898, Mead described the Basin as: “...an immense bowl entirely surrounded by lofty mountains. It has not, however, the appearance of a valley as that term is ordinarily used. The greater part of the surface is hilly and broken. Some of the bad-land ridges rise almost to the dignity of mountains and present a picture of aridity and desolation which disappoints and discourages many of those who visit this section for the first time. None of the broken country can be reclaimed. The limits of irrigation are
} 
The Big Horn Basin also had in spades what any newcomer who tried irrigation had found everywhere in Wyoming. Whether armed with cash, or with only a mule and shovel, everyone - including the state engineer and his staff - met surprises trying to put ideas for water into practice. They were all profoundly ignorant of the ecosystem in which they were working. No one really understood what would be required in finances and engineering to irrigate the terrain, or to grow crops in the climate. There was a steep and painful learning curve, which killed many private irrigation ventures. But there seemed no end to big ideas (Bonner 2007).

In the forbidding Big Horn Basin, among those who dreamed of molding garden spots were some who brought money, some who brought know-how, and some who brought neither. One with money was Solon Wiley, a successful public utilities engineer from Omaha. Starting in 1895 he formed a company and obtained water permits (including the purchase of some permits for projects that had gone nowhere) for a plan to build an irrigation colony on flat bench land above the sizeable Gray Bull (now the Greybull) River. Following an act of Congress offering aid to irrigation projects in the West (an 1894 precursor to the 1902 Reclamation Act), Wiley new act of Congress, he was able to get public lands set aside for his project. Though Wiley was not an absentee entrepreneur but a very hands-on one - personally supervising construction of his canal while his wife cooked for the laboring crews - progress was very slow (Lindsay 1930; Cook 1990). It wasn't clear Wiley could meet his permit construction deadline, set for the end of 1902.

As his canals began to reach some of the land, however, in 1901-1902, Wiley wanted water. He got in an argument with downstream neighbors, the Farmer's Canal - a group of experienced Mormon irrigators, who had farms and a state water certificate for water. Their priority date was 1894; Wiley, whose venture dated from 1895, nonetheless claimed an 1893 date based on the old permits he had bought (Lindsay, 1930; State Engineer 1901-02, 47-53). ${ }^{16}$

The state engineer had to decide what to do. Despite the looming unmet deadline in Wiley's permit, he appreciated Wiley's construction difficulties, and he had some sympathy for getting water to the eager farmers who were living in sod huts at Wiley's colony. He was totally unwilling, however, to give Wiley's project any priority over the Farmers' Canal, where the farmers had been successful in getting water to land and "proving up on" their water right (Attorney General 1901-02, 8-5-1901; Mead-Van Orsdel Correspondence, 12-2-1902).

restricted to the bottoms and table-lands which border the water courses. Outside of this the country is neither adapted to the construction of ditches nor fit for cultivation even if water could be carried to it." (State Engineer 1897-98, 93).

${ }^{16}$ The sale of a water permit, as distinct from a water right, was acceptable, as it essentially simply substituted a new person for the original, in the contract with the state to put water on the lands covered by the permit. (Mead-Van Orsdel correspondence, 11-14-1902) 
The state engineer asked for advice - twice - from the state attorney general, who responded that Wiley should indeed get water, and the priority position he sought, before the Mormon colony. Further, the attorney general said, an unmet construction deadline on Wiley's project would not affect his permit or his priority right to water, whenever he did get everything built (Attorney General 1901-02, 8-5-1901, 6-30-1902.)

To reach that conclusion, the attorney general, Josiah Van Orsdel, outlined a sweeping new view of state water permits and of federally-supported water projects. Van Orsdel declared that state water permits should be regarded as documents that conveyed a germ of a property right (an "inchoate" right, the attorney general called it). The permit holder had to nurture that right, by putting the water to use. The state engineer's office, however, also had a duty - to protect that right at the earliest stages, delivering water before construction was complete (Attorney General 1901-02, 8-5-1901). ${ }^{17}$

The attorney general also declared that state water permits for projects like Wiley's that had federal lands set aside for them were a special case. In that case, he wrote, failure to meet water permit construction deadlines carried no penalty. The germ of a water right conveyed by a permit should not be lost. Since such projects had land set aside for them, it was only logical they should have their water set aside for them too, for as long as it took to get the project built (Attorney General 1901-02, 6-30-1902).

That answer caused an uproar along the Gray Bull River, in the state engineer's office, and beyond (Mead-Van Orsdel Correspondence, 8-19-1902, 11-14-1902). ${ }^{18}$ The state

\footnotetext{
17 In his opinion the next year, Van Orsdel stated that the "inchoate" right conveyed by a Wyoming water permit included a right to change plans on exactly how to get water to the lands targeted for irrigation. He stated that Wiley's pile of permits, since they all covered the same lands and waters, demonstrated merely such changes in plan - and so Wiley could properly date the priority of his right back to the first permit, of 1893.(Attorney General 1901-02, 6-30-1902.). This view is in striking contrast to Mead's publicly stated policy of issuing more permits on the same lands for the same water if original permittees were unsuccessful in putting water to work. Under Mead's policy, new permits covering the old permits' lands had new, later, priority dates. Mead, of course, was the state engineer who issued the series of permits in the mid-1890s for irrigation along the Grey Bull River on lands where Wiley ultimately located his colony. Mead had clearly seen Wiley's project in 1895-96 as worthy of encouragement with a new permit where others had failed - but he was clear that the priority date of the new permit he issued for Wiley was to be 1896. (Mead-Van Orsdel Correspondence, 11-14-1902.)

18 Mead, as the former state engineer now a federal official in Washington, in the fall of 1902 told Van Orsdel flatly that he was wrong, and that such a view "would cause unending confusion, would be unjust to other appropriators on the stream," and violated the Wyoming constitutional language on water that Mead had helped write. (Mead-Van Orsdel Correspondence, 11-14-1902) Mead and Van Orsdel were well acquainted. They had worked together in the 1890s when Mead was state engineer and Van Orsdel a private attorney, and again when the lawyer became the attorney general representing Mead as state engineer. The correspondence between the two on Wiley's project did not begin until after Van Orsdel wrote his June 1902 opinion sparking outrage in the Big Horn Basin in July and August 1902. In midAugust, Van Orsdel decided to query Mead (by then serving as head of "Irrigation Investigations" for the U.S. Department of Agriculture in Washington) about the Wiley permits. Mead in response clearly told Van Orsdel his June opinion was wrong. Mead could recall the exact circumstances of the failure of the first - 1893 - project on the lands in question, and his subsequent issuance of a permit to Wiley. He told Van Orsdel firmly that that permit could only have a priority dating from the time Wiley's company applied for it, in 1896. (Mead-Van Orsdel Correspondence, 11-14-1902). Van Orsdel responded to Mead that "I am aware that I have departed from some of the principles upon which we were always agreed, in my
} 
engineer's office implemented the attorney general's ruling and gave Wiley water, and the Farmers' Canal immediately filed suit. The district court ruled for Farmers' Canal, and against Wiley - overruling Van Orsdel's opinion. (Farmer's Canal 1902-1904) That local court said Wiley could get water he needed - but only after the Farmers' Canal got the water it needed. The court ruling stuck: both projects on the Gray Bull were successfully irrigated under that priority order for some decades after.

All this was, however, only an initial wrangle over just what water use was required for a permit holder to obtain a protected Wyoming water right, with a priority position. There was more to come.

Next up to bat was the U.S. government, which Westerners had begged to take on irrigation as private ventures failed (Lilley and Gould 1966). The new U.S. Reclamation Service of 1902 started one of its first projects in Wyoming's Big Horn Basin, on the Shoshone River just north of the Gray Bull. It acquired an unused permit from $1899-a$ permit with considerable value vis-à-vis the many irrigators who had moved on to the Shoshone soon after that date (Bonner 2007). By 1910, the government's Shoshone project was far from complete; by 1915, the state engineer's office said the valuable 1899 permit was void due to failure to meet construction deadlines. The federal government protested - and pointed to the Wyoming Attorney General's opinion of 1902 on the Wiley Project. Van Orsdel had said that that project's permit was unaffected by missed construction deadlines, and the Reclamation Service demanded the same treatment. His old opinion had a life of its own, and still cast a shadow, despite the district court decision that had effectively overruled it on the Gray Bull. Shown the 1902 opinion by the current Wyoming attorney general, the state engineer reluctantly allowed the federal project to keep its 1899 priority date. (Wyoming State Engineer Correspondence 1915, 12-17-1915, 12-27-1915.) Though later state engineers kept raising the issue, the big federal dam built on the Shoshone supplied so much water to everyone on that river that it drowned out neighbors' initial protests (State Engineer 1921-22, 51-58; Burritt 1935). After years of growing and using more water, the project did not prove up on the old permit to get a state certificate until some 90 years later. ${ }^{19}$

The state engineer's office was concerned about water users missing deadlines statewide, however. With water superintendents short of time and money to get all new water uses adjudicated, some water users ended up content to take water from Wyoming streams as convenient based on their state permits alone (State Engineer 1903-04, 20; State Engineer 1915-16, 86-87). Inevitably, some users naturally believed, as one state engineer had warned they would, that their permits alone had conveyed a "water right of perpetual value," with the priority of the permit application date (State Engineer, 1903-04, 11). In 1916 the state engineer demanded a strict new statement of the original rule, and the legislature enacted it (State Engineer 1915-16, 86-87). Water permit deadlines were to be met, on pain of forfeiture of the permit and

opinion, but I still believe that my opinion to a large extent, will be upheld." (Mead-Van Orsdel Corresondence, 11-24-1902)

${ }^{19}$ On Jan. 23, 2006, Nancy McCann, Big Horn River basin adjudication case manager in the office of the Wyoming Board of Control confirmed the ongoing history of this permit in an email message to the author. 
the priority position involved. Water users had to seek appropriation certificates, requiring superintendent examination and proof of use, within two years of getting water onto land (or, for long pending permits, by 1919) (Session Laws of Wyoming 1917, 119).

Yet this apparent victory quickly dissolved into another defeat. In 1920, the state engineer declared that the statutory requirements had to be relaxed. Many water users had not complied and superintendents couldn't get around to inspect all the water rights that should have been adjudicated (State Engineer 1919-20, 62-63)

The "contract" view of a water permit had lost out - and its defeat, users' property rights in water had gained ground. The rule about how someone got to be a Wyoming water user had become less clear. There was no "or else" penalty attached to permit deadlines. A would-be water user had only to get an agency permit, and with that would get a toe-hold on a priority position in the water use system. A Wyoming water permit came to be regarded, increasingly, as Van Orsdel had regarded it in 1902. It conveyed the roots of a property right to use water, with a certain priority position - a right that must be protected by the state engineer's office.

Consequently, the state agency had less gate-keeping power. There were admittedly still limits on who could get into the world of secure Wyoming water users. A state permit remained, and has remained to this day, an absolute requirement: in Wyoming claims to water rights based on long usage without state permit are rarely made; any such claims are uniformly thrown out (Trelease 1984, 203-205; Lewis v State Board of Control 1985). In the early 20th century, while few water permits were denied (State Engineer 1909-1910, 10), many were issued only after promoters revised their projects. And in fact, many water users did use their permitted water, prove their use, and receive certificates of appropriation. But the aura of private property - the idea that water rights were like private property in land - clung in the minds of some users to the rights they had obtained, whether via permit or certificate.

Meanwhile, water-users had more authority, sometimes determining for themselves what water use actually took place. They took over some of the supervision and enforcement role the state engineer's office had expected to perform. Neighbors might watch to see if water diverted under a permit went to the lands that were originally planned. They might bring an "abandonment" challenge, to show that the right to use the water in question had been forfeited by years of non-use. Neighbors would be the first to know and could object if water that hadn't been used under a permit were suddenly diverted from the stream. A good deal, of course, depended on interpersonal relations on a creek, unrelated to water - whether the local norm was accommodation or intimidation, for instance. The local economy, affecting the current value of water, also made a difference. Neighbors sometimes took the step of challenging each other with abandonment charges, in hopes of using the water in question themselves. Just as 
often, however, they didn't, particularly in hard times - and unused rights stayed on the books. $^{20}$

On this issue of what permits required, the state engineer's original policy was defeated, while earlier on the water sales issue the state engineer's original policy prevailed. What brought on these different results? Clearly, on the permit issue, a user with considerable power and lobbying influence, the U.S. government, played a major role. So too, however, did the ordinary users of all kinds, insignificant except in their numbers, and the division superintendents, who together could not manage to comply with the strict requirements the state engineer sought.

The most telling factor in the final defeat of the state engineer's view of water permits may well have been the location where this question arose, and its symbolic significance. The Big Horn Basin embodied the difficult terrain and the constant irrigation disappointments common to all of Wyoming - as well as the hopes for new communities. Would-be water users statewide, no matter what their size or their finances, all identified with the problems of getting ditches built and water onto land on time. The state engineer's files from the time are full of hand-written letters explaining why permit deadlines couldn't be met. In cases of small water users, the state engineers often canceled water rights for failure to meet deadlines, despite good excuses. ${ }^{21}$ It was, of course, the federal government and its Reclamation program that pushed the outer limits of a Wyoming water permit so far that it was hardly recognizable as the contract once envisioned by the state engineer's office. But the federal program

\footnotetext{
${ }^{20}$ Neighborhood monitoring of water use is well-known in modern Wyoming and appears to have been common from the late 19th century on. For modern examples of other users on a stream bringing up objections to permits long unused going into use, see Green River Development v. FMC 1983 and Wyoming State Board of Control, Order, Lonesome Fox Corp. 1981. , I-81-4-4, Order Record Book No. 27, 19, in the files of the Board of Control, Cheyenne, Wyo. These are only the more famous examples, brought to public attention, of the longstanding common practice of neighborhood monitoring. A fiction piece by the son of a longtime Wyoming ranching family uses humor to point out that neighbors all using the same creek are not necessarily the picture of order and concord. In that tale, any attempt at intervention by state water commissioners leads only to more hilarious discord. (Budd 1990, 48-58.) For an instance of intimidation preventing neighbors from effective monitoring, an interview by the author with a division superintendent in 2000 noted that on one creek an old man with senior water rights raised no objection to a junior right holder depriving him of water, because the junior right holder was a younger, bigger man who had physically threatened him. The superintendent did not intervene on this creek unless an actual complaint against the modus operandi was filed with him - and it was not. (Interview notes in author's files). For interesting examples of contrasting reports on neighbors' tolerance of each others' patterns of water use or nonuse, all from 1919-20 (which covered a very bad drought year, and a depressed agricultural economy in Wyoming), see State Engineer 1919-1920, 72 ("many" abandonment petitions had come before the board) and 81-82 (juries were refusing to convict in charges of water theft where the unchallenged facts showed illegal use of water; and there were many examples of unused water rights where neighbors were not pursuing abandonment challenges.)

${ }^{21}$ On Sept. 30, 1918, for instance, Ron Nebeker of Sage, Wy, wrote State Engineer James True (in a handwritten note on notebook paper): "I was sick all summer and was not able to work. I wish you would give me a little more time to finish this ditch as it will not benefit me any other place than where it is now begun." State Engineer True, who had had to give in to the federal government's pressure in 1915, replied firmly that Nebeker's permit had expired - and if he wanted to continue the ditch, he would have to file for a new permit, which would necessarily have a later priority date. (Wyoming State Engineer Correspondence, 1918)
} 
embodied the kind of settlement policy and investment yearned for not only in the Big Horn Basin but also in most of the rest of Wyoming outside the capitol city. ${ }^{22}$ Ultimately, perhaps, what won the day was the ordinary water user's painful experience with just how hard it was to turn Wyoming prairies and benches into irrigated farms.

The state's water managers, meanwhile, had watched the users' troubles with increasing concern. By the 1920s, irrigation growth in downstream states contrasted sharply with agricultural depression in Wyoming. The engineer's office, by the 1920s, had become eager to be flexible, ready to stretch the rules to keep permits alive - in order to help get water onto Wyoming land. Otherwise they feared that, under newly emerging court decisions on interstate water rights, neighboring states could establish use and rights to all the water of a river. ${ }^{23}$

So by the 1920s, on the question of what water use was required to get a water right, the initial idea of the state engineer's office gave way to a reality recognized by both users and administrators.

The rule that settled into place instead, allowing water rights to be rooted in a permit alone, inevitably brought into water management a trace of land management thinking. ${ }^{24}$ On the earlier water sales issue centered on Little Horse Creek, Wyoming

\footnotetext{
${ }^{22}$ In 1911, the Wyoming Legislature created a Board of Immigration charged with recruiting farmers and capital to Wyoming. In 1912 the commissioner of the board reported "Wyoming has anything but an enviable reputation among prospective homeseekers, immigrants, or investors." (Larson 1978, 363-4).

${ }^{23}$ State Engineer Frank Emerson in 1922, having questioned the persistence of the federal permit on the Shoshone and held a hearing on it, succinctly and poignantly stated the problem all too clear to Wyoming state engineers by the 1920s. The public interest must govern state engineer decisions, he wrote - and in the case of permit extensions and expiration, the public interest went two ways. First, there was the importance of protecting individual appropriators who had pursued and obtained valid water rights. Second, however, there was the interest of the state and its people as a whole, situated at the headwaters of major rivers, in supporting the development of water in Wyoming in competition with growth in water use in other states. "The State of Wyoming, for its part, is materially interested in the interstate phase of the question, and in having priorities sustained in this state as far as possible...the State Engineer of Wyoming must consider the interests of the State and sustain priorities to the use of water so far as same can be validly held." (State Engineer 1921-22, 54-55). Over several years before 1922, court decisions had pointed in the direction of enforcing priority dates across state lines, which meant that early development in a neighboring state on a river could preclude later development in another state on the same stream. Emerson cited some of those cases in his discussion of the Shoshone permit. Concern over the implications of that legal principle was one of the factors leading Wyoming, Colorado and other states to pursue successfully in the 1920s the idea that interstate compacts, allocating water among states on an interstate stream for future use, could with the approval of Congress become law and so pre-empt the application of priority dates across state lines. (Tyler 2003, 15-20.). The flagship in this effort was the Colorado River Compact of 1922, which Wyoming State Engineer Frank Emerson helped make happen. (Tyler 2003, 218). That was the same year that Emerson made the decision to continue to sustain the Shoshone River permit, in part due to interstate concerns. Emerson was elected governor four years later (the only Wyoming state engineer to have been so rewarded.) ${ }^{24}$ The influence of land law was hard to avoid in the Wyoming of the early 20th century, where the federal land office and the courts were crowded with people claiming federal land. The popular mechanism for disposal of the federal public lands, the homestead law, was in heavy use, with plenty of land still available for settlers to take up. Homestead law included the precept that an initial permit was the base of a final secure right - it was "an appropriation of the land" - if it were followed up with a "good faith" and "diligent" (however unsuccessful) effort to settle the land. (Spaulding 1884, secs. 76, 80, 103, 106). That
} 
water users and the engineer's office had, with their opposition to water sales, reflected an understanding of the difference between land and water. With their actions a few years later on permits, following the Big Horn Basin cases, they sidestepped that distinction in their eagerness to get Wyoming water into use no matter how long it took. That meant that users wound up, in the 1920s, with more property rights in water giving them more authority over water use.

\section{CONCLUSION: WHAT THEY WROUGHT}

Twenty-five years of implementation of water management in Wyoming in the early 20th century significantly changed the system.

The original state-run system put water into the hands of private water users, but maintained considerable public control. There would be inspection of the uses those private parties achieved, and continued supervision. The supervision would ensure that successful water use remained attached to the lands originally intended, and that unsuccessful ventures were replaced by better ideas. When the words of first State Engineer Mead are translated via the analytic framework of Schlager and Ostrom (1992), it becomes apparent that the state agency was expected to act as the resource owner, holding the rights to exclude users and to determine how they would use the water. The water users were merely authorized users of the resource, with the right to access the water and to withdraw it (within limits set by the agency). ${ }^{25}$

principle seemed to echo in Van Orsdel's 1902 discussion of the "inchoate right" conveyed by Wyoming water permits. Homesteading continued well into the 20th century in Wyoming, peaking in 1919-1921, "despite the devastating drought of 1919, which should have given pause to even the most land hungry and speculation prone," the state's historian has commented. (Larson 1978, 173-8, 362, 414-416).

Van Orsdel's favored term for what a water permit conveyed - an "inchoate right" - had historically been used in law in connection with private property rights; and it likely carried that implication for him and for his readers in the opinions he wrote in 1901-02. See Black's Law Dictionary. It seems only appropriate that a few years after his opinions on the Wiley permits, Van Orsdel became a judge on the District of Columbia Court of Appeals, where he was a classic laissez-faire jurist and demonstrated a strong interest in proper administrative procedure. (Morris 2001, 68, 73-77) Administrative law concerns the rules governing how executive agencies implement the will of Congress; a significant portion of it deals with agency interaction with private property rights. Van Orsdel's experience as attorney general advising fledgling Wyoming state agencies - when he could have seen the state engineer's office as not unique but simply one among many - may have sparked his interest in administrative law. In turn, this mental bent in his mature years as a judge may illuminate his 1902 view, when he may have seen the state engineer's office as just like the familiar federal General Land Office, charged with churning a public resource into private property, no less and no more.

${ }^{25}$ Mead stated that the state of Wyoming, as owner, retained in theory the right to alienate or transfer Wyoming water entirely out of its hands (State Engineer 1895-96, 41). Schlager and Ostrom (1992) point out that the right of alienation is one of the attributes of ownership. Mead described the Wyoming rationale for not acting on that power as follows: "It is admitted that if the State, the unquestioned owner, were to sell a stream to the highest bidder and authorize the purchaser to exact tribute from users the transactions would outrage public sentiment and seriously menace our prosperity and development. Our laws, therefore, make no provision for the sale by the State of water rights. Only those prepared to beneficially use water and those who have so used it can obtain rights in our streams by appropriation." How then, Mead went on to ask, could it be proper to allow such a user subsequently to claim ownership of the water and the right to sell it to anyone else? He most likely had a situation like that on Little Horse Creek in mind (since the water sale on Little Horse Creek had just occurred, and he had refused to allow 
There were also assumptions about how this arrangement might change, should change ever be needed. The expectation was that change would come from the two key players who had set up the original system in 1890: The state administrative agency and the legislature.

Issues emerged that the initial system and its statutes did not address, however - areas of uncertainty highlighted in the Little Horse Creek and Big Horn Basin controversies.

By the 1920s, after working through those issues, the public via the state remained the owner of the water, but state administrators had more limited power to determine who could use water and how. The agency had sole say over who got a permit to use water, and for what purpose, and it could find that the public interest forbade permits for a certain project. The agency could not always, however, eliminate permit holders from the user group. It could not supervise as planned. It could not know whether permitholders were using water as they had stated; and it could not always require that deadlines for getting water into use were met. It had often to rely on users to monitor each other's water use, thus developing what use patterns they saw fit.

Water users thus had more management powers over water than under the original system. They reached the status of claimants, in the terms of Schlager and Ostrom (1992). They were not, however, able to treat their water as they did their land. They could not sell their water off to someone else. And any variation in use from what was set forth in their permit or certificate had to be accepted, at the least by their neighbors.

his water commissioner to honor it). He argued against the idea that water users were actually owners of Wyoming water, whose rights included alienation or sale of water. "According to this remarkable doctrine we can accomplish by indirection what our law admittedly does not permit to be done directly. The appropriator from the State can give a better title than he receives and can be safely permitted to make of water a speculative commodity, although the State, its original proprietor, has no such right" under the water statutes. (State Engineer 1895-96, 41) Two years earlier, Mead had expressed the same view this way: "There is no question but what absolute ownership would be more valuable to the individual securing control of the stream than the right to use water for beneficial purposes, but we have never believed that the purpose of the State in assuming control of the water supply and protecting appropriators in its use was for the purpose of conferring a valuable property right on individuals to the exclusion of the rights of the public." (State Engineer 1893-94, 40.) Mead attempted in these public essays to educate and persuade a typical member of the public who, he said, "has usually regarded an appropriation of water in much the same light as he regards acquiring title to land, and looks on nothing less than absolute ownership as adequate and proper. We have never been able to accept that view." (State Engineer 1893-94, 39-40) To protect the interest of later users and the state in continued, orderly and stable development of Wyoming water and the Wyoming economy, Mead wrote, limits on a water user's property rights were necessary. He saw a property right in water in Wyoming as very different from a property right in land - a distinction that Van Orsdel clearly did not fully grasp.

With the court decision of 1904 rejecting Mead's view of water sales (and upholding the Little Horse Creek sale) Wyoming water users briefly became what Schlager and Ostrom would identify as claimants or even quasi-proprietors of water - just short of being owners. Until the 1909 statute made it clear that water sales were not allowed, users had the option of managing their water by letting part of it be used on other people's lands (for a price), as the Springvale ranch did on Little Horse Creek. The 1909 statute passed at the instance of water users and the state engineer turned the situation around by clearly prohibiting such sales. Wyoming water users thereby became again merely "authorized users," to use the terms of Schlager and Ostrom (1992). 
The holder of a water right still was not the "owner" of water. She was not free to dispose of water, as she might "own" and dispose of land. ${ }^{26}$

Most important is how these changes were made: by user participation. Water users had become major players in defining the relationship between themselves and the state agency. Together they and the agency - not the legislature and the agency made the rules. They jointly arrived at an arrangement on who had what powers over water. In 30 years of change the legislature played only the minor role of codifying the principles arrived at by the agency, the water users, or both. What the written Constitution of the State of Wyoming had to say about water did not change (and has not changed, since 1890), but the underlying constitution of the state's water management system did change - a new constitutional choice was made, in Ostrom's terms (2005) - with this change in who set the rules governing the daily choices available to water users.

A system of neither centralized state control nor private ownership, the working arrangement of water management in Wyoming relied on complex interaction between the state engineer's office and the water users. The state engineer and the users together set the rules; the state engineer kept the records and articulated the rules; in many locations the users monitored and enforced the rules; the state engineer, in turn, became the monitor and enforcer when the users exhausted what they could do locally. The response to violations of the rules ranged from enforcement of a set pattern of water use, to monetary fines, to loss of the right to use the water. ${ }^{27}$ Disputes over water use went to the local water commissioner, then to the superintendent, then to the state engineer, and then to the Board of Control, and rarely to court. The process was lowcost and user-friendly, with no need for a lawyer except in court. ${ }^{28}$ The state agency,

\footnotetext{
${ }^{26}$ The limits of water-users' rights were less noticeable, of course, if they lived on a very abundant stream, or a stream with few users, or in a very remote area. Then they might de facto have the rights of proprietors, dealing with very few restrictions not of their own making - perhaps even acting as de facto owners, and selling water rights off of their land (though evidence of this is hard to find, since the practice was illegal after 1909.) Those situations, of course, were not uncommon in the Wyoming of 1900-1925, where transportation remained difficult and population sparse. In those situations, rules that water users set would prevail unless they couldn't agree and someone called in the state engineer's office, and with it the system of rights de jure, by law.

${ }^{27}$ In cases over the period 1900-1925 Wyoming water division superintendents individually or acting as the Board of Control made decisions that covered the gamut of these sanctions: they cut back the water use of a senior user found to be wasting water, and thereby made water available for a junior user who had formerly had none (Nichols v. Hufford 1913): the state's high court upheld the board's action); they encouraged county attorneys' pursuit of statutory fines against those who took water for which they had no water rights (State Engineer, 1919-1920, 80-81): Supt. Lou Blakesley however complained that juries did not readily convict for violation of the statutes against unlawful taking of water); and superintendents acting as the Board of Control declared water rights no longer valid because use of the water had been abandoned (State Engineer 1919-1920, 72).

${ }^{28}$ All the processes involving state water officials, and specifically actions before the Board of Control, were consciously designed to be low-cost. Mead considered a water-user's easy access to dispute resolution without high professional fees a key feature of a functioning water management system, and one of which he was particularly proud in Wyoming where, he noted, few disputes actually reached the courts. (Mead 1903, 247, 256-259). Water users' costs, and their use of attorneys, have remained relatively low through the modern period.
} 
dealing with a small population in a large area, became less the locus of centralized control and more the chosen agent of the users. The rest of society paid considerable respect to the autonomy of the managers-users group: on water matters, the legislature acted at their request, not on its own initiative.

Lawyers attempting to work with and analyze this system have found it rather murky involving a property right that could not be sold, its use governed by rules that could change depending on the situation, but might not be stated in statutes or court decisions. ${ }^{29}$ To the users and the state engineer's office, however, the system seemed rather straightforward and practical. They worked together and, though sometimes at odds, they didn't have to call on lawyers too much; the rules they put together were stable enough that people could and did invest in land, ditches and reservoirs.

For an outsider working with the system, it can be most useful to think of Wyoming water management as a system that, with considerable user involvement, distributes varied rights to a scarce common pool resource between an administrative agency and users. ${ }^{30}$ Wyoming people dealing with water found that this arrangement, with its

\footnotetext{
${ }^{29}$ From a lawyer's point of view, the puzzle was that water users did not have a right to treat water as their own private property like land, but they had a use right; official rule on what use was allowed might not be the rule applied, depending on the local situation - until the state engineer's office was called in (the sign of a failed centralized regulatory structure?, a lawyer might ask herself); the rules might change over time in practice on the ground, or under the decisions of the board of control, but the change would not necessarily show up in the statutes and there might be no court decision to confirm it.

On the matter of the "use right" viewed by a lawyer: Courts have called a water right a "usufructory" right. That is a term imported from civil law, based in turn on Roman law. A "usufruct" (usufruit, in French law), is "the right of enjoying a thing, the property of which is vested in another, and to draw from the same all the profit, utility, and advantage which it may produce, provided it be without altering the substance of the thing," according to Black's Law Dictionary. A "usufructuary," (the noun) is "one who has the usufruct or right of enjoying anything in which he has no property," the dictionary notes. A concept from Roman and civil law, patched in to American legal reasoning, can be awkward for an American lawyer dealing with the common law system adopted in the U.S. from England. The idea of a usufructory right does, however, fit reasonably well into Mead's - and Schlager and Ostrom's - systems of delineating property rights. It fits, for instance, the distinction made by Schlager and Ostrom (1992) between proprietors and owners, and by Mead between a water user and the state. Interestingly, in Roman and civil law a "usufructuary" cannot acquire his use rights through prescription (ie by continuous use without permission over a long period), but only by a clear delegation from the owner. (Nicholas 1969, 105, 111). That is in harmony with Mead's insistence that Wyoming water rights, after statehood, could be acquired only by permit, the principle which has persisted to this day.

${ }^{30}$ The system, by 1925 , demonstrated what Ostrom (1990) has found to be characteristic principles of common property ownership systems that endure: clear boundaries defining the resource and who gets to use it (water in all of Wyoming, used only by people who get state agency authorization); rules for water use that fit local conditions; user participation in setting rules; a graduated scale of sanctions for people who violate rules; a good monitoring system to catch violations; low-cost dispute resolution; and general recognition of the right of people in Wyoming to create their own institution to manage Wyoming water (recognized in general by Congress, and specifically by the Wyoming Legislature, which since the early 1900 s has left users and administrators to create their own rules which the legislature acts only to codify if necessary.)

On Congress' recognition of Wyoming citizens' right to create their own water management system: Congress had of course admitted Wyoming territory as a state in 1890, with its Constitution proclaiming state ownership of water. Further, however, through a succession of general legislation, from 1866 through the Reclamation Act of 1902, Congress explicitly deferred to the states in the matter of water law.
} 
attributes of a common property system rather than a centralized state system or a private property system, was the practical way to manage water in the physical and social circumstances in which they found themselves. Much of this decision had to do with simply the size, topography and climate in the area the Wyoming water system attempted to cover, and the era when it began, with technology and transportation remaining rudimentary. It demonstrates a fundamental adjustment of a human institution to meet the social and environmental circumstances surrounding it. ${ }^{31}$

As Mead put it when a young engineer:

"..a climate so different from that of the East as to profoundly modify the structure of plants and the colors and habits of animals required a corresponding modification of laws and institutions to bring human settlement into harmony with its environment." (Mead 1902, 3)

As it turned out, the physical and social environment also required modification of Mead's own ideal of a centralized system, the system once hailed as a model for other Western states.

How the Wyoming system changed over subsequent years, and whether it can meet today's changing economic and social conditions is a topic for another day. What the history examined here does suggest, however, is that water in the American West may be usefully seen as being under a form of community management rather than a regulated private property scheme.

(Dunbar 1983, 51, 77-78.) Later acts of Congress - the Clean Water Act of 1972 and the Endangered Species Act of 1973, for instance - have created federal initiatives that have considerable impact on state water management decisions, but even such statutes (due to the agitation of Western senators and congressmen) have typically been amended to include provisions to state that either (in the case of the Clean Water Act) nothing in the statute should be interpreted to "supercede or abrogate" water rights under state law, or at least (in the case of the Endangered Species Act) that federal agencies must cooperate with state agencies to "resolve water resources issues." (Clean Water Act 1972; Endangered Species Act 1973).

${ }^{31}$ Wyoming 1900-1925 clearly was well-supplied with one factor in incremental institutional change identified by North (1990, 83-89): difficulty of rules enforcement, giving rise to entrepreneurial opportunities to change an institution such as a property rights system. 


\section{LITERATURE CITED}

Books, journals and government documents

Agrawal, A. 2002. Common resources and institutional stability. In The drama of the commons, Ostrom, E., T. Dietz, N. Dolsak, P. Stern, S. Stonich, and E. Weber, eds. Washington, DC : National Academy Press.

Anderson, T. and P. Hill. 1975. The evolution of property rights: A study of the American West. Journal of Law and Economics, 18:163

Attorney General of Wyoming. Biennial Report, 1901-02. Cheyenne, WY.

Berkes, F. and C. Folke. 1998. Linking social and ecological systems for resilience and sustainability. In Linking social and ecological systems: Management practices and social mechanisms for building resilience. F. Berkes and C. Folke, eds. New York: Cambridge University Press.

Blomquist, W. 1992. Dividing the waters: governing groundwater in southern California San Francisco, CA: ICS Press.

Blomquist, W, E. Schlager and T. Heikkila. 2004. Common waters, diverging streams: Linking institutions and water management in Arizona, California, and Colorado.

Washington, DC: Resources for the Future.

Bonner, R. 2007 William F. Cody's Wyoming Empire: The Buffalo Bill Nobody Knows. Norman: University of Oklahoma Press.

Bromley, D. 1992. The commons, common property, and environmental policy. Environmental and Resource Economics, 2:1-17.

Budd, B. 1990. A Wide Spot in the Road. Woodlands, TX: Laffing Cow Press.

Burritt, E. 1935. Report on Water Rights of Shoshone Irrigation District. Cheyenne, WY: Wyoming State Engineer's Office.

Cook, J. 1990. Wiley's Dream of Empire: The Wiley Irrigation Project. Private printing: Jeannie Cook.

Davis, J. W. 1993. A Vast Amount Of Trouble: A History Of The Spring Creek Raid. Norman, OK: University of Oklahoma Press.

Davis, J. W. 2005. Goodbye, Judge Lynch: The End of a Lawless Era in Wyoming's Big Horn Basin. Norman, OK: University of Oklahoma Press.

Dietz, T., N. Dolsak, E. Ostrom, and P. Stern. 2002. The drama of the commons. In The drama of the commons, Ostrom, E., T. Dietz, N. Dolsak, P. Stern, S. Stonich, and E. Weber, eds. Washington, DC : National Academy Press.

Dunbar, R. 1983. Forging New Rights in Western Waters. Lincoln, NE: University of Nebraska Press 
Folke, C., F. Berkes and J. Colding. 1998. Ecological practices and social mechanisms for building resilience and sustainability. In Linking social and ecological systems:

Management practices and social mechanisms for building resilience. F. Berkes and C. Folke, eds. New York: Cambridge University Press.

Hardin, G. 1968. The tragedy of the commons. Science 162 (3859): 1243-1248. http://www.sciencemag.org/archive/1968.dtl

Hardin, G. 1978. "Political Requirements for Preserving Our Common Heritage." In Wildlife and America: Contributions to an understanding of American wildlife and its conservation. Washington DC: Council On Environmental Quality.

Hays, S. 1969. Conservation \& the gospel of efficiency. 2d ed. New York: Atheneum Publishers.

Holling, C., F. Berkes and C. Folke. 1998. Science, sustainability and resource management. In Linking social and ecological systems: Management practices and social mechanisms for building resilience. F. Berkes and C. Folke, eds. New York: Cambridge University Press.

Kenney, Douglas. 2001. Conference Report: Two Decades of Water Law and Policy Reform: A Retrospective and Agenda for the Future. Boulder, CO: Natural Resources Law Center, University of Colorado School of Law.

Kluger, J. 1992. Turning on Water With a Shovel: The Career of Elwood Mead. Albuquerque: University Of New Mexico Press.

Larson, T.A. 1978. History of Wyoming. 2d edition. Lincoln, NE: University of Nebraska Press.

Lilley, W. III and G. Gould. 1966. The western irrigation movement, 1878-1902: A reappraisal." In The American West: A reorientation, G. Gressley, ed. Laramie, WY: University of Wyoming:.

Lindsay, C. 1930. The Big Horn Basin. Lincoln, NE: University of Nebraska Press.

Mead, E. 1902."The Growth of Property Rights in Water." The International Quarterly VI, 1: $1-12$

Mead, E. 1903. Irrigation institutions: A discussion of the economic and legal questions created by the growth of irrigated agriculture in the West. Reprin, 1972. New York: Arno Press

Morris, J. 2001. Calmly to poise the scales of justice: A history of the courts of the District of Columbia Circuit. Durham, N.C.: Carolina Academic Press.

Nicholas, B. 1969. An Introduction to Roman Law. 2d ed. New York: Clarendon Press. North, D. 1990. Institutions, institutional change and economic performance. New York: Cambridge University Press. 
Ostrom, Elinor. 1990. Governing the commons: The evolution of institutions for collective action. New York: Cambridge University Press.

Ostrom, E., T. Dietz, N. Dolsak, P. Stern, S. Stonich, and E. Weber, eds. 2002. The drama of the commons. Washington, DC : National Academy Press.

Ostrom, E. 2005. Understanding institutional diversity. Princeton, NJ: Princeton University Press.

2007. A diagnostic approach for going beyond panaceas. PNAS 104, no. 39 (2007): 15181-15187

Rose, C. 2002. Common property, regulatory property, and environmental protection: Comparing community-based management to tradable environmental allowances. In The drama of the commons, Ostrom, E., T. Dietz, N. Dolsak, P. Stern, S. Stonich, and E. Weber, eds. Washington, DC : National Academy Press.

Schlager, E. and W. Blomquist. 2008. Embracing watershed politics. Boulder, CO: University Press of Colorado.

Schlager, E. and E. Ostrom. 1992. Property-rights regimes and natural resources: A conceptual analysis. Land Economics 68 (3): 249-62.

Spaulding, George W. 1884. A treatise on the public land system of the United States : with references to the land laws, rulings of the departments at Washington, and decisions of courts : and an appendix of forms in United States land and mining matters. San Francisco: A.L. Bancroft. Available online at The Making of Modern Law. Gale. 2010.

http://galenet.galegroup.com/servlet/MOML?af=RN\&ae=F106376255\&srchtp=a\&ste=14

State Engineer's Office, Wyoming. Biennial Report. (1891-present)

-1895-96, portions reprinted in Shields, J. and A. MacKinnon, eds. 2000.

Selected writings of Elwood Mead on water administration in Wyoming and the West.

Cheyenne, WY: Wyoming State Engineer's Office. Available online at http://seo.state.wy.us/PDF/FinalMeadBooklet.pdf

Tarlock, A. D. 1988. New commons in Western waters. In Water and the American West: Essays in Honor of Raphael J. Moses. Getches, D., ed. Boulder, CO: Natural Resources Law Center, University of Colorado School of Law.

Territorial Engineer's Office, Wyoming, 1889. Annual Report.

Tyler, D. 2003. Silver fox of the Rockies: Delphus E. Carpenter and Western water compacts. Norman, OK: University of Oklahoma Press.

Trelease, Frank J. 1984. Cases and materials on water law: Resource use and environmental protection. 3rd ed. St. Paul, MN: West Publishing Company.

Wilson, J. 2002. Scientific uncertainty, complex systems, and the design of commonpool institutions. In The drama of the commons. Ostrom, E., T. Dietz, N. Dolsak, P. Stern, S. Stonich, and E. Weber, eds. Washington, DC : National Academy Press.

Wilkinson, C. 1992. The eagle bird: Mapping a new West. New York: Pantheon Books. 
Court cases and statutes

Clean Water Act. 1972. U.S. Code 33, sec. 1251(g)

Constitution of the State of Wyoming. Accessible online at http://legisweb.state.wy.us/LSOWeb/wyStatutes.aspx

Endangered Species Act. 1973. U.S. Code 16, sec. 1531(c)(2)

Farm Investment v. Carpenter, 9 Wyo. 110, 61 P. 258 (1900)

Green River Development v. FMC, 1983 Wy. 20

Johnston v. Little Horse Creek Irrigating Co., 13 Wyo. 208, 79 P. 22 (1904)

Lewis v. State Board of Control, 1985 WY 63, 699 P 2d 822.

Nichols v. Hufford, 21 Wyo. 477, 133 P. 1084 (1913):

Session Laws of Wyoming. Territorial to current year. Cheyenne, WY.

Wyoming Revised Statutes. Pre-1890. Cheyenne, WY.

Wyoming Compiled Statutes. 1890- mid 20th century. Cheyenne, WY.

Wyoming Statutes Annotated. Lexis-Nexis. Accessible online at

http://legisweb.state.wy.us/LSOWeb/wyStatutes.aspx

\section{Archival material}

District court files:

- Farmers' Canal Co. vs. Big Horn Basin Development Co., 4th Judicial District Court, Basin, Big Horn County, Civil Case \#182. Wyoming State Archives.

- Johnston v. Little Horse Irrigating Co., Laramie County District Court, 1st Judicial District, civil case file 6-233, Box 2. 1891-95. Wyoming State Archives, Division of Cultural Resources, Department of State Parks and Cultural Resources.

- Smith v. Devoe, Case No. 234, District Court of Johnson County, 1889. Transcript of testimony. Available in case file of Zezas v. Board of Control, 714 Pacific 2d, (Wyo., 1986), Wyoming Supreme Court Case 85-78, Wyoming State Archives. Division of Cultural Resources, Department of State Parks and Cultural Resources. 
Mead-Van Orsdel Correspondence. Elwood Mead, Chief of Irrigation Investigations for the US Department of Agriculture and Wyoming Attorney General J.A. Van Orsdel.

- Van Orsdel to Mead, Aug. 19, 1902. Wyoming Attorney General correspondence (outgoing), 1898-1906, RR517, Box 1, Letterbook vol. 3, 161-2. Wyoming State Archives

- Mead to Van Orsdel, Nov. 14, 1902: Wyoming Attorney General correspondence (incoming), 1901-1904, K-M, RR517, Box 2. Wyoming State Archives, Division of Cultural Resources, Department of State Parks and Cultural Resources.)

- Van Orsdel to Mead, Nov. 24, 1902 and Dec. 2, 1902, Wyoming Attorney General correspondence (outgoing), 1898-1906, RR517, Box 1, Letterbook vol. 3, 196-199, 206-7. Wyoming State Archives).

Wyoming State Board of Control, Order, Lonesome Fox Corp. 1981. Case I-81-4-4, Order Record Book No. 27, 19, in the files of the Board of Control, Cheyenne, Wyo.

Wyoming State Engineer Correspondence

- 1915. Wyoming State Engineer, Administrative Records, General Correspondence June-December 1915, RG 0037, Wyoming State Archives.

- Wyoming State Engineer James B. True to Willis J. Eggleston, District Counsel, Great Falls, MT, U.S. Reclamation Service, Department of Interior, Dec. 17,1915

- Willis J. Eggleston, District Counsel, Great Falls, MT, U.S. Reclamation Service, Department of Interior to James B. True, Wyoming State Engineer, Dec. 27,1915

- 1918: Wyoming State Engineer, Administrative Records, General Correspondence September-October 1915, RG 0037, Wyoming State Archives. 